\title{
The Dynamics Of Financial Liberalisation In Ghana
}

Erasmus L. Owusu, University of South Africa (UNISA), South Africa Nicholas M. Odhiambo, University of South Africa (UNISA), South Africa

\begin{abstract}
This paper examines the role of financial liberalisation policies in Ghana and it finds that financial liberalisation policies have had positive effects in Ghana. However, the paper also finds that the same financial liberalisation policies have brought with them a number of interrelated problems that should be addressed by the country. These include the large interest rate spread, an increase in foreign currency deposits, constant depreciation of the domestic currency, a drastic increase in imports, and the reduction of credits to the productive sectors of the economy, as well as the problem of high lending rates which has discouraged investment in the productive sectors of the economy. The extent to which the government should intervene in the financial market to "guide" credit is still under discussion. The paper concludes that, on the whole, financial liberalisation policies have had beneficial effects in Ghana.
\end{abstract}

Keywords: Economic Growth; Financial Liberalisation; Ghana; Financial Development; Stock Market Development and Foreign Currency Deposits

\section{INTRODUCTION}

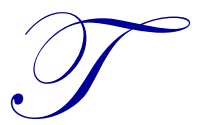

he financial liberalisation hypothesis, since first suggested by McKinnon (1973) and Shaw (1973), has advanced from focusing on credit markets and interest rates to including the private sector and the capital accounts. In some of the recent studies, the debate has focused on the dynamics of the liberalisation of debt (bonds) and equity markets and the effect of this on economic growth in developing countries. The policy in Ghana has brought to light some of the weaknesses of the financial liberalisation hypothesis. However, recognising these drawbacks does not made the hypothesis deficient, but rather it tells us that policymakers can attempt to solve the problems in various ways - by taking into consideration the specifications of each country. Alongside financial liberalisation, particular attention should be given to institutional development and the peculiarities of each country.

Under normal circumstances, in a country like Ghana with a high degree of openness $(50.0 \%$ in 1990 and $81.6 \%$ in 2007), successful financial liberalisation would be considered to effect a shift of resources from foreign currency deposits to domestic currency deposits, and from being a component of the leakage to the formal financial sector because of an increase in the deposits rates; but instead, there was a strong condition for the phenomenon of currency substitution. Currency substitution, as measured by the amount of foreign currency deposit in the domestic banks, stood at $17.8 \%$ of total deposits in 1990 . This increased to $28.1 \%$ in 2008 , reaching a high of $60.1 \%$ in 1996 .

The purpose of this paper is to provide insight into the effects of financial liberalisation policies in Ghana (a member of the Economic Community of West African States - ECOWAS ${ }^{1}$ ). The paper contributes to the literature on financial liberalisation by establishing whether financial liberalisation policies have had any beneficial effects in the economy of Ghana.

\footnotetext{
${ }^{1}$ The Economic Community of West African States is made up of 15 countries in the in the West African sub-region, namely: Benin, Burkina Faso, Cape Verde, Ivory Coast, Gambia, Ghana, Guinea-Bissau, Guinea, Liberia, Mali, Niger, Nigeria, Senegal, Sierra Leone and Togo.
} 


\section{THE ROLE OF FINANCIAL LIBERALISATION IN GHANA}

Ghana has pursued a growth strategy policy which can best be described as based on an inward-oriented trade policy, led by the public sector and aimed at the achievement of social welfare objectives (Aryeetey, 1994). As a result, the budgetary pressures and the fast depleting external reserves, which led to shortages in the Ghanaian economy in the 1960s, forced the introduction of price control policies for the administrative allocation of scarce goods and services. This extended to the financial services as well. By the mid-1960s, the price control regime became official, with the establishment of a Price and Income Board. In the financial sector, banks were forced to provide credit - based on social and political considerations - and making sure that these credits are channelled into priority sectors, such as agriculture.

In order to cope with the cost of credit, the exchange rate and interest rates were fixed by the government. The price control regime brought about distortions in the market that led to the misallocation of resources). Economic growth rates declined, as a result of price distortions, which affected the production of the real sector of the economy. Control of the foreign exchange market led to an over-valuation of the domestic currency, which weakened the export sector at the expense of an increased appetite for foreign goods, thus worsening the balance of payments. According to Sowa and Acquaye (1999), the control of interest rates, together with the high rate of inflation, brought about a system of financial repression which weakened the development of the financial sector and subjected the allocation of credit to political patronage.

An integral part of this inward-oriented policy strategy was the control which the government had over the financial sector (ibid). There were interest rate ceilings, both on deposits and credits, and there was no stock market. Government policies favoured the mobilisation of savings and the allocation of credits through government-owned financial institutions (Bank of Ghana, 1988). Despite this policy of favouritism, the mobilisation of domestic savings by the banks was unsatisfactory. For instance, between 1969 and 1986, financial deepening in Ghana, as measured by the ratio of M2 to GDP, averaged $17.3 \%$. This poor performance could be attributed to: 1) Citizens' lack of confidence in the financial sector during that period, 2) low deposit interest rates (fixed by the government), and 3) the emergence of large-scale migration of Ghanaian workers - especially to Nigeria and Libya, for "greener pastures". All these factors led to an increase in the underground market in various commodities.

Although it is difficult to ascertain or determine the magnitude of such activities, the proportion of narrow money (M1) held as currency (outside Banks) might be an indication of the magnitude of such activities (Serieux, 1993, and Shaw, 1973). For example, the average ratio of currency outside banks to M1, between 1969 and 1986, averaged $53.1 \%$. This may indicate how large the black and the underground markets were during the pre-financial liberalisation era. All these issues led to an economic meltdown.

The country was then forced to implement an Economic Recovery Programme (ERP) in 1983. This included macro-economic stabilisation and institutional reforms aimed at the liberalisation of prices. The price control regime was abolished and the processes of interest rate liberalisation and capital accounts liberalisation were vigorously pursued.

\section{THE TRENDS OF INTEREST RATES AND STOCK MARKET DEVELOPMENT IN GHANA}

Interest rate liberalisation in Ghana started in 1987, with the abolition of the minimum and maximum deposit rates. However, the rates on lending were left unchanged. In 1989, banks and other financial institutions were allowed to determine their lending rates, but interest rates were not fully liberalised until 1991. According to the financial liberalisation hypothesis, the removal of interest rate controls should lead to an increase in financial savings, investments and, hence economic growth. In Ghana, as observed from Table 1, total financial savings increased from 1969 until 1983 when they started to decrease from the previous year's level of $\$ 0.23 \mathrm{~b}$ to $\$ 1.11 \mathrm{~b}$.

The rapid decrease in total deposits that occurred between 1982 and 1984 was caused primarily by some measures taken by the Provisional National Defence Council (PNDC) government to eliminate fraud (including freezing certain banks deposits pending investigations for tax liability), the withdrawal of some denominations of the domestic currency from circulation, and a rampant change of currency notes - leading to a loss of confidence in 
the domestic currency and the banking system as a whole. This trend continued through to 1986 and then stabilised during the next two years. In 1989, financial savings started picking up steadily, through to 1995, even though the level was still low compared to those of the late 70's and the early 80 's. This trend reversed after the implementation of the full interest rate liberalisation policy in 1990.

Table 1

Financial Savings, Interest Rates, Foreign Direct Investment (FDI) and Exchange Rates in Ghana between 1969 and 2008

\begin{tabular}{|c|c|c|c|c|c|c|c|}
\hline Year & $\begin{array}{c}\text { Total } \\
\text { Financial } \\
\text { Savings }^{\mathrm{a}} \text { in } \\
\text { Billion, US\$ }\end{array}$ & $\begin{array}{l}\text { Of which } \\
\text { Foreign } \\
\text { currency } \\
(\%)\end{array}$ & $\begin{array}{c}\text { Nominal } \\
\text { Lending } \\
\text { Rate }^{\mathbf{b}} \\
(\%)\end{array}$ & $\begin{array}{c}\text { Nominal } \\
\text { Deposit } \\
\text { Rate } \\
(\%)\end{array}$ & $\begin{array}{c}\text { Nominal } \\
\text { Discount } \\
\text { Rate } \\
(\%)\end{array}$ & $\begin{array}{c}\text { Foreign direct } \\
\text { investment }(\mathbf{\$ m})\end{array}$ & $\begin{array}{c}\text { Exchange rate } \\
\text { Cedis per US } \\
\text { dollar(\$) }\end{array}$ \\
\hline 1969 & 0.23 & 12.6 & $\mathrm{n} / \mathrm{a}$ & $\mathrm{n} / \mathrm{a}$ & 5.5 & $\mathrm{n} / \mathrm{a}$ & 1.02 \\
\hline 1970 & 0.27 & 8.2 & $\mathrm{n} / \mathrm{a}$ & $\mathrm{n} / \mathrm{a}$ & 5.5 & 67.8 & 1.02 \\
\hline 1971 & 0.30 & 1.0 & $\mathrm{n} / \mathrm{a}$ & $\mathrm{n} / \mathrm{a}$ & 8.0 & 30.6 & 1.03 \\
\hline 1972 & 0.32 & 2.9 & $\mathrm{n} / \mathrm{a}$ & $\mathrm{n} / \mathrm{a}$ & 8.0 & 11.5 & 1.33 \\
\hline 1973 & 0.45 & 0.5 & $\mathrm{n} / \mathrm{a}$ & $\mathrm{n} / \mathrm{a}$ & 6.0 & 14.4 & 1.17 \\
\hline 1974 & 0.55 & 2.2 & $\mathrm{n} / \mathrm{a}$ & $\mathrm{n} / \mathrm{a}$ & 6.0 & 14.3 & 1.15 \\
\hline 1975 & 0.76 & 0.5 & $\mathrm{n} / \mathrm{a}$ & $\mathrm{n} / \mathrm{a}$ & 8.0 & 70.9 & 1.15 \\
\hline 1976 & 1.04 & 1.5 & $\mathrm{n} / \mathrm{a}$ & $\mathrm{n} / \mathrm{a}$ & 8.0 & -18.3 & 1.15 \\
\hline 1977 & 1.60 & 0.9 & $\mathrm{n} / \mathrm{a}$ & $\mathrm{n} / \mathrm{a}$ & 8.0 & 19.2 & 1.15 \\
\hline 1978 & 1.60 & 0.7 & 19.0 & 11.5 & 13.5 & 9.7 & 1.76 \\
\hline 1979 & 1.20 & 1.0 & 19.0 & 11.5 & 13.5 & -2.8 & 2.75 \\
\hline 1980 & 1.50 & 1.5 & 19.0 & 11.5 & 13.5 & 15.6 & 2.75 \\
\hline 1981 & 2.22 & 2.3 & 19.0 & 11.5 & 19.5 & 16.3 & 2.75 \\
\hline 1982 & 2.84 & 2.1 & 19.0 & 11.5 & 10.5 & 16.3 & 2.75 \\
\hline 1983 & 1.11 & 2.6 & 19.0 & 11.5 & 14.5 & 2.4 & 8.83 \\
\hline 1984 & 0.40 & 4.4 & 19.0 & 15.0 & 18.0 & 2.0 & 35.99 \\
\hline 1985 & 0.44 & 9.6 & 20.5 & 15.8 & 18.5 & 5.6 & 54.34 \\
\hline 1986 & 0.40 & 7.6 & 22.5 & 17.0 & 20.5 & 4.3 & 89.20 \\
\hline 1987 & 0.40 & 15.6 & 26.0 & 17.6 & 23.5 & 4.7 & 153.73 \\
\hline 1988 & 0.40 & 16.6 & 25.0 & 16.5 & 26.0 & 5.0 & 202.35 \\
\hline 1989 & 0.66 & 18.0 & 23.5 & $\mathrm{n} / \mathrm{a}$ & 26.0 & 15.0 & 270.00 \\
\hline Average & 0.89 & 5.35 & 20.92 & 13.72 & 13.36 & 14.50 & - \\
\hline 1990 & 0.66 & 17.8 & 23.5 & $\mathrm{n} / \mathrm{a}$ & 33.0 & 14.8 & 326.33 \\
\hline 1991 & 0.80 & 17.6 & 25.5 & 21.3 & 20.0 & 20.0 & 367.83 \\
\hline 1992 & 0.92 & 15.1 & 24 & 16.3 & 30.0 & 22.5 & 437.09 \\
\hline 1993 & 0.90 & 23.2 & 29.0 & 23.6 & 35.0 & 125.0 & 640.06 \\
\hline 1994 & 0.87 & 28.5 & 38.0 & 23.2 & 33.0 & 223.0 & 956.71 \\
\hline 1995 & 0.99 & 32.3 & 38.5 & 28.7 & 45.0 & 106.5 & 1200.43 \\
\hline 1996 & 0.65 & 60.1 & $\mathrm{n} / \mathrm{a}$ & 34.5 & 45.0 & 120.0 & 1637.23 \\
\hline 1997 & 0.80 & 55.7 & $\mathrm{n} / \mathrm{a}$ & 35.7 & 45.0 & 81.8 & 2050.17 \\
\hline 1998 & 0.96 & 45.3 & $\mathrm{n} / \mathrm{a}$ & 32.1 & 37.0 & 167.4 & 2314.15 \\
\hline 1999 & 1.21 & 15.4 & $\mathrm{n} / \mathrm{a}$ & 23.6 & 27.0 & 243.7 & 0.2668 \\
\hline 2000 & 8.46 & 42.1 & 47.0 & 28.6 & 27.0 & 165.9 & 0.5452 \\
\hline 2001 & 9.99 & 33.2 & 44.0 & 30.9 & 27.0 & 89.3 & 0.7167 \\
\hline 2002 & 1.35 & 33.2 & 38.5 & 16.2 & 24.5 & 58.9 & 0.7928 \\
\hline 2003 & 1.74 & 30.3 & 35.5 & 14.3 & 21.5 & 136.8 & 0.8673 \\
\hline 2004 & 2.15 & 29.3 & 28.8 & 13.6 & 18.5 & 139.3 & 0.9000 \\
\hline 2005 & 2.47 & 29.2 & 26.0 & 10.2 & 15.0 & 145.0 & 0.9068 \\
\hline 2006 & 3.50 & 28.1 & 24.3 & 8.9 & 12.5 & 636.0 & 0.9169 \\
\hline 2007 & 4.76 & 22.3 & 24.2 & 8.9 & 13.5 & 970.4 & 0.9355 \\
\hline 2008 & 6.05 & 28.1 & 27.2 & 11.2 & 17.0 & 2120.4 & 1.0570 \\
\hline Average & 2.59 & 30.90 & 31.39 & 20.10 & 27.71 & 294.56 & - \\
\hline
\end{tabular}

Notes: ${ }^{\text {a }}$ Demand, Savings, Time and Government deposits

b All the figures are end-of-year average rates.

Source: Compiled from IMF, International Financial Statistics (2009). Bank of Ghana, Quarterly Economic Bulletin, various issues and Ghana Statistical Services, Quarterly Statistical Digest, various issues 
Following this policy, the financial savings increased continuously for a period of 12 years and then dropped drastically from almost $\$ 10 \mathrm{~b}$ in 2001 to $\$ 1.35 \mathrm{~b}$ in $2002^{2}$. After this massive drop, financial savings started to improve again, increasing consistently from 2002 to 2008 - due to the prevailing political and economic stability in the country. As can be seen in Table 1, financial savings have increased by about $190 \%$, on the average, since the implementation of the interest rate liberalisation policy, compared to those of the pre-liberalisation period. This was mainly due to the relatively higher interest on deposits offered by the banks compared with other asset types.

As can be seen from Table 1, interest rates have been on the increase since liberalisation. Deposit rates started at $11.5 \%$ in 1978 but ended up at $16.5 \%$ before the policy ended in 1989 with a yearly average of $13.7 \%$. Even the full interest rate liberalisation in 1991 could not reverse the trend. The rate rose to a high of $35.7 \%$ in 1997 , then dropped to as low as $8.9 \%$ in 2006 and $11.3 \%$ in 2008 . The average for the post-liberalisation period is therefore $20.1 \%$.

This is about 6 percentage points over that of the pre-liberalisation average. Furthermore, the discount and lending rates followed the same trend as the deposit rate; for example, the lending rate started at $19.0 \%$ in 1978, but in 1988 , it stood at $25.6 \%$ with a pre-liberalisation average of $20.9 \%$. After full interest rate liberalisation, the trend continued to be upwards, reaching $47.0 \%$ in 2000 but dropping to $27.3 \%$ in 2008 with an average of $31.4 \%$, thereby showing an increase of about 10 percentage points. Comparing real interest rates, it was found that while the average real deposit rate pre-financial liberalisation was negative at $-39.5 \%$. The figure was negative, at $-1.6 \%$, after the implementation of the interest-rate liberalisation policy, showing an increase of 37.9 percentage points ${ }^{3}$.

The real discount and lending rates followed a similar trend. On the average, the real lending rate before interest rate liberalisation was negative, at $-30.0 \%$, but the real discount rate was negative $28.5 \%$ by 2008 , and the averages were $8.4 \%$ and $4.2 \%$, respectively.

The McKinnon-Shaw hypothesis holds the view that the removal of interest rate ceilings would lead to an increase in the real deposit rates. As can be seen from the above analysis, it may be said that the hypothesis is verified in the case of Ghana as real interest rates have gone up while the total financial savings have started increasing, however, with a significant portion being in foreign currency. It is also worth noting that following the adoption of the unified flexible exchange rate, the black market dealings in foreign exchange virtually disappeared and the foreign exchange resources of the black market were almost completely absorbed by the formal sector.

This was reflected in the rapid increase in the proportion of foreign currency deposits in the domestic banks. Related to this is the decline in the size of the underground market economy, as measured by the decrease in the ratio of currency outside banks to narrow money (M1). The average of the ratio of currency to M1 pre-financial liberalisation was about $56 \%$, while that of the post-financial liberalisation was about $51 \%$. The decrease of 5 percentage points may suggest the magnitude of the average reduction in the underground economy. However, it can be seen from Figure 1 that since 1992, the ratio has been increasing, reaching its peak of $77 \%$ in the year 2000 and then falling back to $39 \%$ in 2007 . This was probably due to the fact that with increasing inflation over the period, the demand for money has increased and therefore Ghanaians chose to hold more cash rather than to deposit it with the banks. Proponents of capital account liberalisation argue that implementation of the policy would lead to an increase in economic growth. As can be seen in Figure 1, it is not entirely clear whether the liberalisation of the capital accounts led to an increase in the economic growth levels. Since the year 2000, there has been a drastic increase in the gross domestic product - from $\$ 4,977.5 \mathrm{~m}$ to $\$ 16,123.4 \mathrm{~m}$ in 2008 - and a similar trend has been seen in stock market capitalisation figures.

\footnotetext{
${ }^{2}$ This is because of capital flight resulting from political uncertainty and change in financial reporting.

${ }^{3}$ This was calculated by adjusting the average nominal interest by the average inflation.
} 
Figure 1: Gross Domestic Product and Sock Market Capitalisation in Ghana (1975 - 2008)

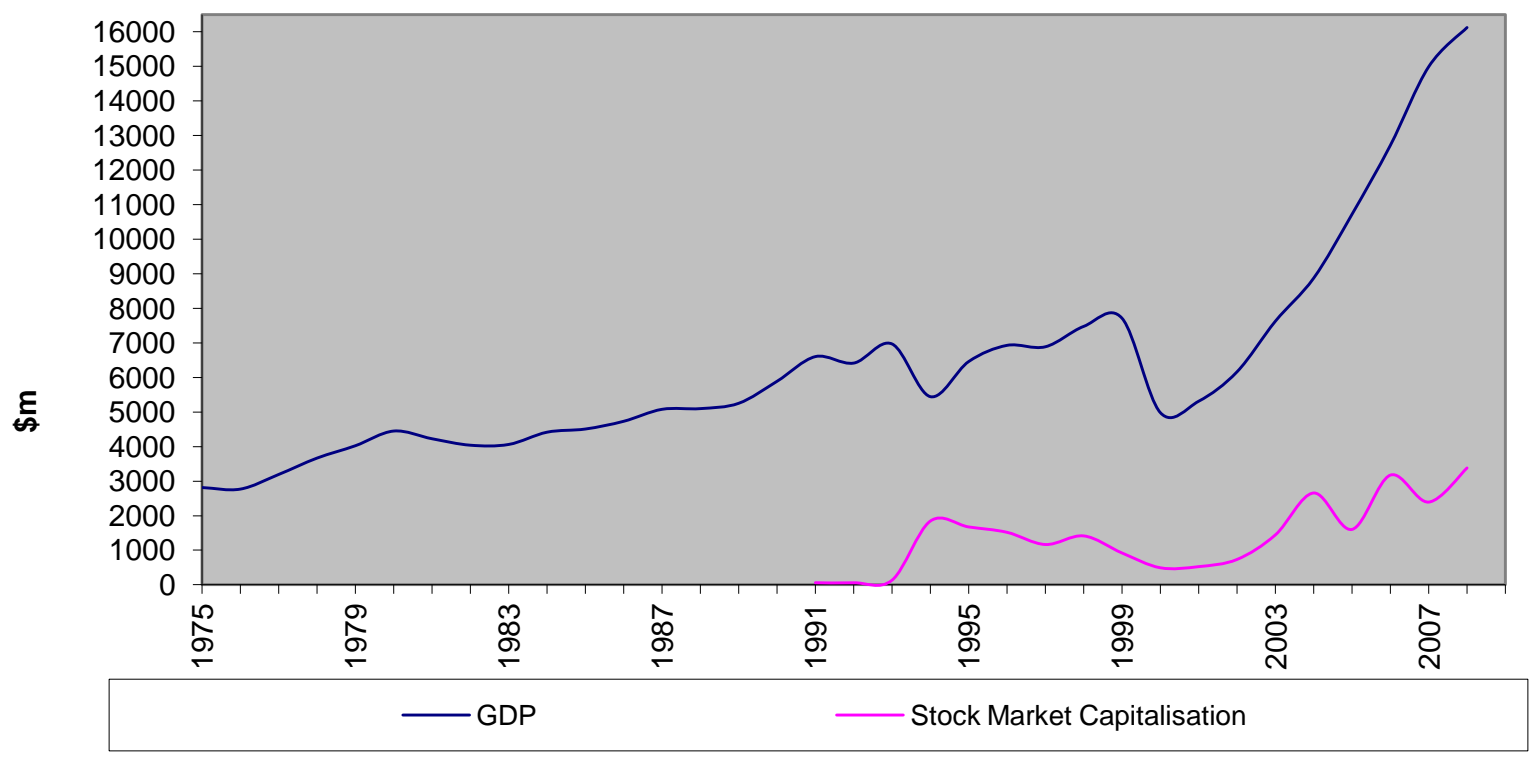

Source: Compiled from World Bank’s Africa Development Indicators (2009).

\section{Figure 2: Ecomonic growth and Selected Stock market indicators for Ghana (1991 - 2008)}

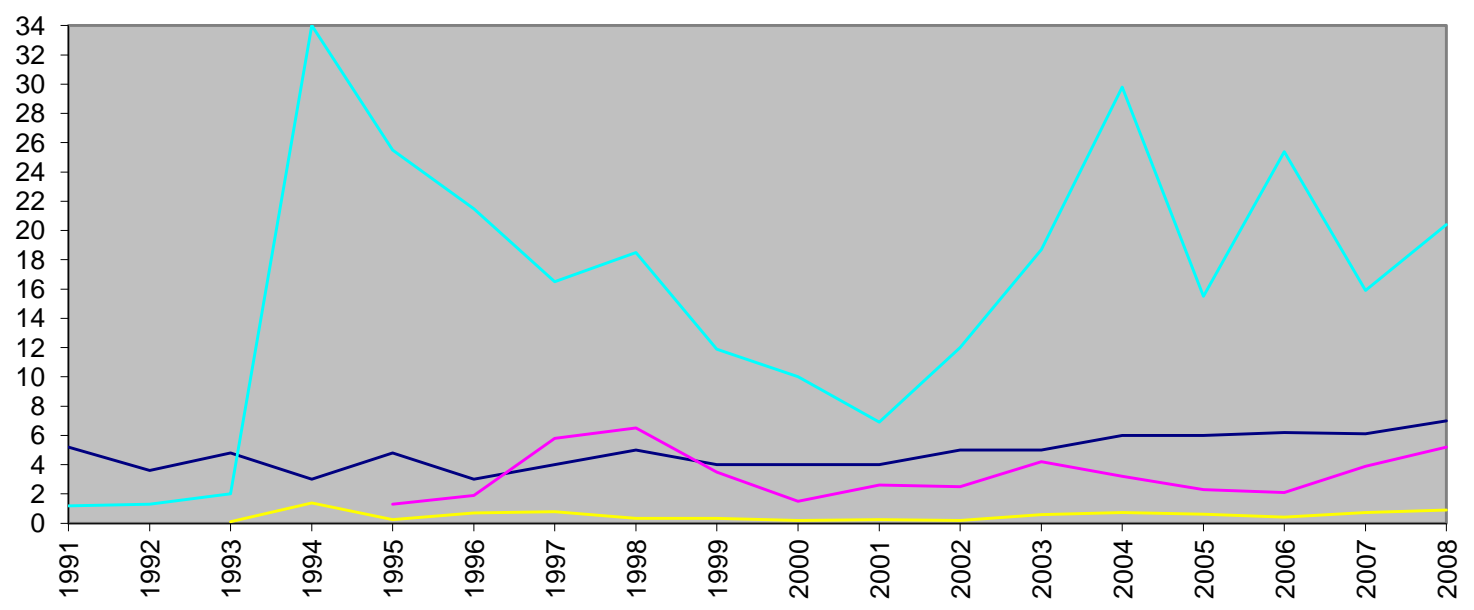

$\begin{array}{ll}- \text { GDP Growth rate (\%) } & \text { Stock Turnover (\%) } \\ \text { Stock Value Traded (\% of GDP) } & \text { Market Capitalisation (\% of GDP) }\end{array}$

Source: Compiled from World Bank's African Development Indicators, 2009 and IMF International Financial Statistics (2009). 
Furthermore, in looking at Figure 2, it may be seen that of all the selected stock market development indicators; i.e., stock value traded as a percentage of GDP, stock turnover as a percentage of market capitalisation, and stock market capitalisation as a percentage of GDP, both have similar trends to that of economic growth.

As can be seen in Figure 2, the stock turnover ratio, which is an indication of the liquidity of the exchange, has been very low and stable since inception of the exchange. It started at $1.3 \%$ in 1995 , then increased to $5.8 \%$ in 1997 and $6.5 \%$ in 1998. However, it tumbled to $1.5 \%$ in 2000 and then bounced back to $2.6 \%$ in 2001. It then stayed around these levels until 2007 when it increased to $3.9 \%$ and then to $5.2 \%$ in 2008 . The stock value that traded as a percentage of GDP and GDP growth rates followed the same trend as the turnover ratios. On the other hand, the market capitalisation as a percentage of GDP fluctuated between a maximum of 32\% in 1994 and $1.2 \%$ in 1991, the year records began. Between 2003 and 2008, the figure had been averaging about 21\%. In 2008, the figure stood at $20.4 \%$, which may suggest that they found their long-term levels.

\section{CHALLENGES FACING THE FINANCIAL REFORM IN GHANA}

Ghana, like many other ECOWAS countries, has faced a number of challenges since the implementation of interest rate liberalisation as part of the ERP in 1986. Apart from high and increasing interest rates, as discussed in the above section, some of the challenges that Ghana has experienced since the implementation of a financial liberalisation policy relate to the mixed savings, investment and financial deepening trends, changes in the sectorial allocation of credit, a low economic growth rate in relation to financial depth, the wide spread between lending and deposit rates, and foreign currency deposits. These sets of challenges are discussed separately below.

\section{Interest Rate Liberalisation, Investments and Financial Deepening}

The McKinnon-Shaw hypothesis postulates that financial liberalisation should lead to an increase in savings, increased investment, and hence rapid economic growth. While in the pre-financial liberalisation period, the average proportion of the GDP invested was $9.6 \%$ which increased by more than two-fold to $21.9 \%$ after the financial liberalisation policy.

This increase was not via an increase in domestic savings only, but also via borrowing from the international organisations and donor countries, which reached 33.0\% in 2006 and 2007 (World Bank, 2009). On the other hand, the savings ratio, which began almost on the same level as investments before the financial liberalisation rate increased to $13 \%$ in 1996 , then tumbled to a low of $3 \%$ in 2005 . At the same time, the flow of foreign direct investments (FDI) into the country increased from a mere average of $\$ 14.5 \mathrm{~m}$ before liberalisation to an average of $\$ 294.5 \mathrm{~m}$ after the period of financial liberalisation.

One other positive outcome of the financial liberalisation is the increase in capital flow and the consequential augmentation of the country's foreign exchange reserves. Prior to the financial liberalisation, the stock of total reserves (minus gold) was $\$ 347.3 \mathrm{~m}$ in 1989 , which increased to $\$ 2,090.3$ by the end of 2006 . The increase in FDI could be attributed to several factors - one relating to the reduction in the country's risk premium, as a result of the relatively macro-economic stability, and the flexible exchange rate regime following the implementation of the financial liberalisation policy. As the financial liberalisation programme stayed on course, the credibility of the country increased and its risk premium diminished, leading to an increase in FDI. The increased workers' remittances from abroad ${ }^{4}$ - through the official channels, have also contributed to the increase in the country's foreign exchange reserves. Another factor that might be responsible for the increased FDI could be the relative political stability, which now prevails in the country.

Financial deepening, as measured by the ratio of M2 (money and quasi-money) to GDP, as observed in Figure 3, started falling in 1980 - from $20.0 \%$ to $10.0 \%$ in 1984. It then rose by $4 \%$ points to $14.0 \%$ in 1989 . It has since been increasing, reaching a high of $29.0 \%$ in 2007 . This level is, however, the highest in the country's economic history. It is hoped that as the financial liberalisation programme stays on track and the financial system

\footnotetext{
${ }^{4}$ This is estimated to be about $\$ 2.0$ billion in 2008 . 
matures, together with the capital account liberalisation, financial assets, such as stocks and bonds (issued by both government and firms), will appear on the financial market and that with the growth in income, financial deepening would also increase.

This is because, among other things, with an increase in the real rate of return on financial assets, assets held previously in the form of large inventories, gold, land, and livestock would find their way into the formal financial system. It should be noted, however, that the main aim of financial liberalisation is to cause a shift of savings from lower productivity self-investment to higher productivity investment intermediated by the formal financial sector.

Figure 3: Investment, Savings, Financial Deepening and Currency outside banks for Ghana, 1969-2008

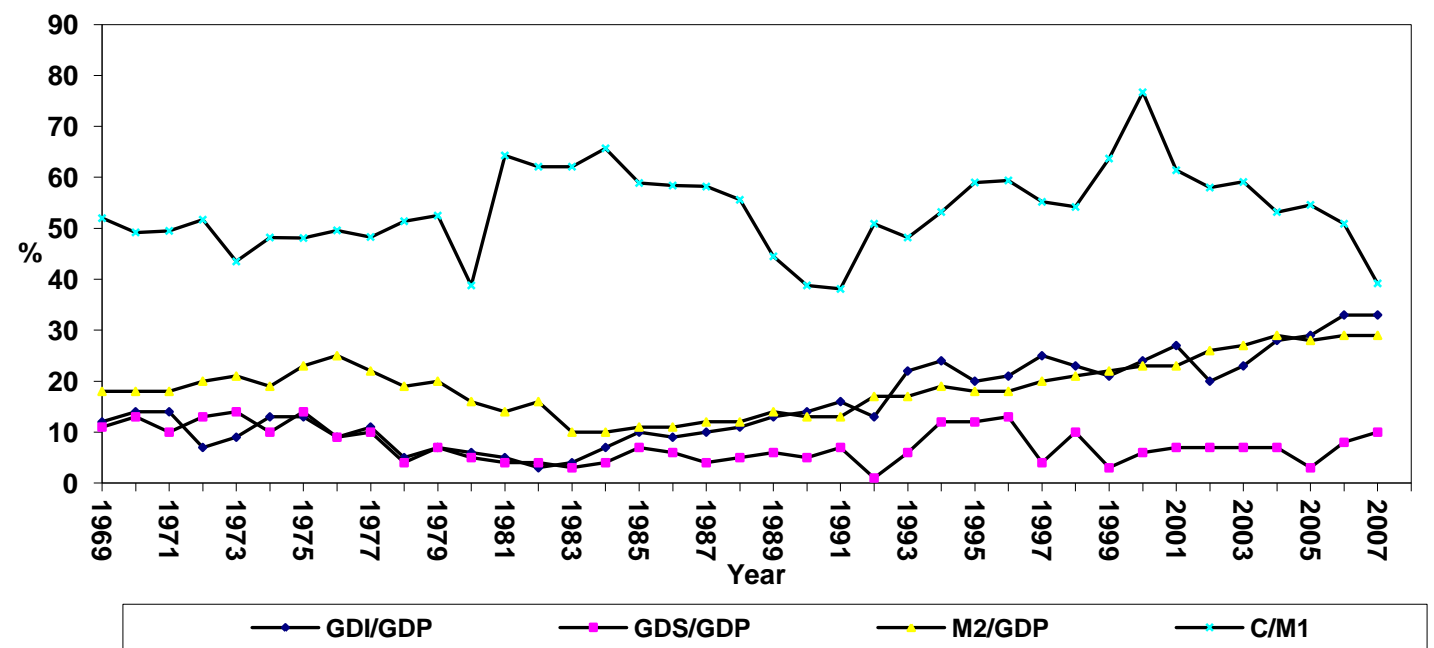

Note: GDI-Gross Domestic Investment, GDP-Gross Domestic Product, M2-Broad Money, M1- Narrow Money, GDS-Gross Domestic Savings, C - Currency in circulation Source: Compiled from World Bank's Africa Development Indicators (2009). IMF, International Financial Statistics (2009).

\section{Interest Rate Liberalisation and Sectorial Credit Allocation}

There has been a tremendous change in the structure of credit allocated to the various sectors by the banks, both before and after the removal of credit controls in 1990, and full interest rate liberalisation in 1991 (see Figure 4). While during the pre-financial liberalisation period, Agriculture, Forestry and Fishing, Manufacturing, Construction, and Trade and Commerce were allocated, on the average, $22.0 \%, 29.3 \%, 11.0 \%$, and $20.0 \%$ of the total credit, respectively, the post-financial liberalisation situation shows Agriculture at 10.2\%; Manufacturing at 23.7\%; Construction at 9.8\%, and Trade and Commerce at $4.7 \%$. It is obvious that while the proportion of credits allocated to the Agricultural sector has halved, those of Trade and Commerce have gone up, suggesting the relative profitability of these two sectors. The question that logically follows would be: "Does this change in the composition of the credit allocation reflect an increase in the efficiency in credit allocation resulting from the liberalisation policies?" 
Figure 4: Sectoral allocation of credit by commercial banks in Ghana between
$1984-2008$.

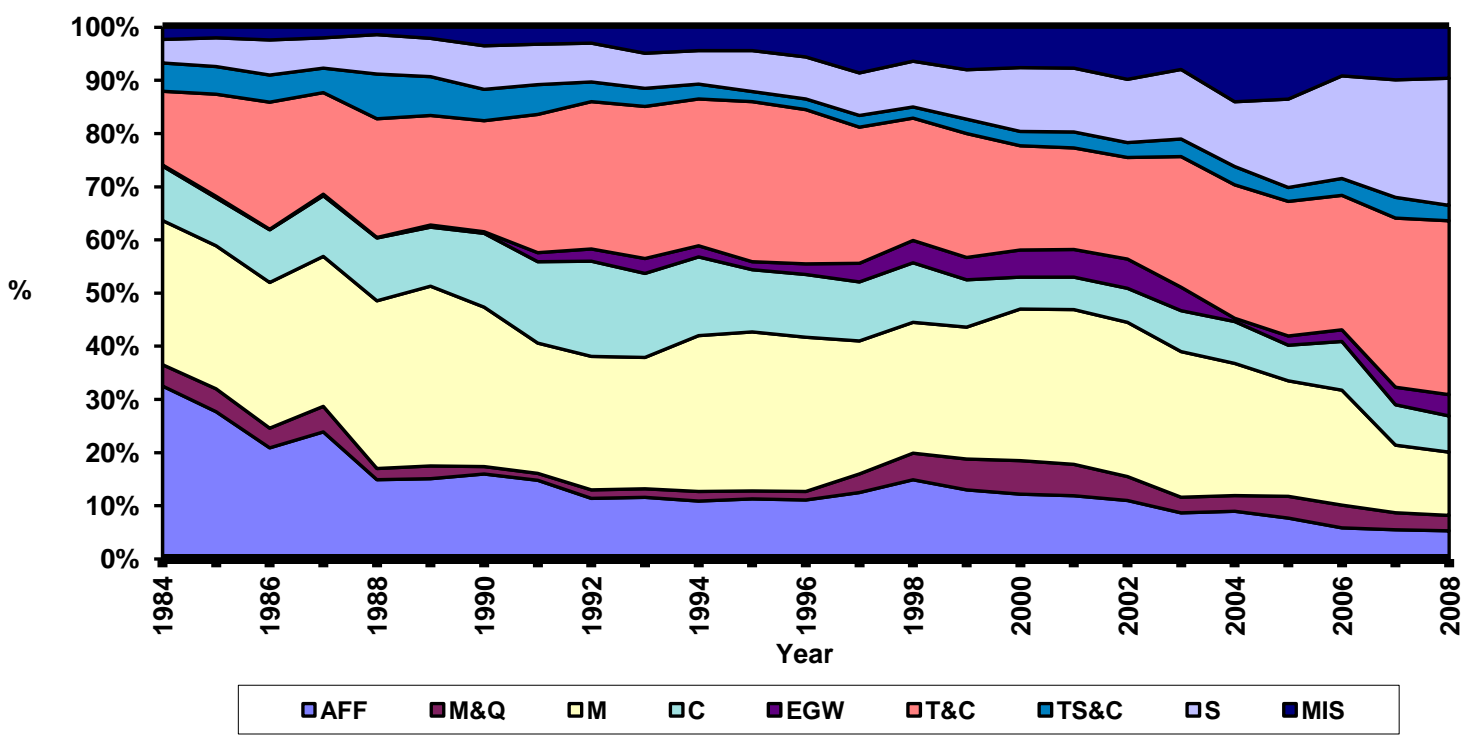

Notes: AFF - Agriculture, Fishing and Forestry (include. Cocoa Marketing); M\&Q - Mining and Quarrying; M- Manufacturing; C - Construction; EGW - Electricity, Gas and Water; T\&C - Trade and Commerce; TS\&C - Transport, Storage and Communication; S - Service; MIS - Miscellaneous.

Source: Compiled from Bank of Ghana, Quarterly Economic Bulletin and Ghana Statistical Society's Ghana in Figures, various issues.

The allocative efficiency of credit in an economy can be measured in several ways, the best of which is probably to compare marginal returns on capital investment across different sectors of the economy. If the marginal returns in different sectors are equal, one may say that the economy allocates credits efficiency - on the assumption that risk, uncertainty and transaction costs are kept constant. Due to the non-availability of data, it was difficult to obtain accurate estimates of marginal returns on credits in different sectors of the Ghanaian economy.

One alternative was to compare the cost of credit in different sectors on the assumption that firms, in order to maximise their profits, would equate their marginal cost of capital and marginal rate of return on investment. This approach has been used by Cho (1988) to study the efficiency of credit allocation after financial liberalisation in South Korea, and the same approach is taken in this paper. It is hypothesised that credit allocation in an economy has become efficient (or at least more efficient) if borrowing costs in different sectors of the economy are equalised (or the differences in borrowing costs are reduced).

Following this conceptual framework, calculations on the Ghanaian sectorial borrowing costs were made. The borrowing cost of each sector was calculated between 1980 and 2008 by dividing total interest and discount payments by the total amount of debt in each sector, which included all sources ${ }^{5}$ of borrowing ${ }^{6}$. The variation in the borrowing cost reflects the differential borrowing costs for different sectors, as offered by the banks. On the assumption that with an increase in efficiency in credit allocation, the variance of borrowing cost of the sectors

\footnotetext{
${ }^{5}$ Since data on informal sector credit activities were not available, this paper uses only the formal financial sector borrowings (i.e., all the Deposit Money Bank)

${ }^{6}$ Again, because of the non-availability of data, this paper uses the average cost of borrowing in each sector instead of the marginal cost of borrowing.
} 
should decrease, the following results were obtained, as shown in Table 2. The results from Table 2 show that the variances before financial liberalisation were relatively smaller, except in 1984, when it jumped from the previous year's figure of zero to 4 and then tumbled to 1 in 1985, then falling to 0.07 in 1986, and subsequently to 0.23 in 1990.

The average variance for the pre-liberalisation period was therefore 0.7. The situation after the financial liberalisation, however, shows a relatively steady increase from 1991 - reaching 6.36 in 1998. This has been the situation since then, reaching 8.13 in 2002 and 7.19 in 2007, and then falling to 5.48 in 2008. The average for this period is, therefore, 5.08 .

This shows an increase in lending risk between the periods before and after the financial liberalisation by $647 \%$ on the average. The results obtained must be interpreted with caution since the underlying assumptions of the concept used in the analysis are strong ${ }^{7}$. One should also note that it is not clear whether a lower variance of cost of borrowing between the sectors is an indication of allocative efficiency and also no adjustment for risks were made in the interest rate figures.

Table 2: Cost of Borrowing (Credits) of Different Sectors of the Ghanaian Economy

\begin{tabular}{|c|c|c|c|c|c|}
\hline Year & Average $^{\mathbf{a}}(\boldsymbol{\%})$ & Variance & Year & Average $^{\mathbf{a}} \mathbf{( \% )}$ & Variance \\
\hline 1980 & 19.00 & 0.00 & 1995 & 39.72 & 2.30 \\
\hline 1981 & 19.00 & 0.27 & 1996 & 39.94 & 5.60 \\
\hline 1982 & 19.00 & 0.07 & 1997 & 43.00 & 5.66 \\
\hline 1983 & 19.00 & 0.00 & 1998 & 39.00 & 6.36 \\
\hline 1984 & 21.17 & 4.00 & 1999 & 36.50 & 4.60 \\
\hline 1985 & 21.17 & 1.00 & 2000 & 47.00 & 5.66 \\
\hline 1986 & 20.00 & 0.07 & 2001 & 43.75 & 6.19 \\
\hline 1987 & 25.50 & 0.70 & 2002 & 38.50 & 5.13 \\
\hline 1988 & 25.58 & 0.80 & 2003 & 35.25 & 5.48 \\
\hline 1989 & 26.07 & 0.30 & 2004 & 28.75 & 5.13 \\
\hline 1990 & 26.04 & 0.23 & 2005 & 26.00 & \\
\hline 1991 & 26.16 & 1.32 & 2006 & 24.25 & 5.30 \\
\hline 1992 & 24.19 & 2.53 & 2007 & 24.17 & 6.54 \\
\hline 1993 & 31.25 & 2.75 & 2008 & 27.25 & \\
\hline 1994 & 30.25 & 5.30 & & & 5.19 \\
\hline
\end{tabular}

${ }^{\mathrm{a}}$ All the figures are end-of-year averages.

Source: Compiled from Bank of Ghana, Quarterly Economic Bulletin, various issues and Ghana Statistical Service, Quarterly Statistical Digest and Ghana in figures, various issues

However, the results provide an initial step toward an in-depth research into the allocative efficiency of credits in Ghana after the financial liberalisation policy; therefore, an inference could be made from it. According to Aryeetey (1994), this apparently lower level of efficient allocation of credits under financial liberalisation in Ghana may be due to a number of institutional, structural, and financial constraints created under the repressed regime and the apparent lack of medium-term financing, the rudimentary nature of the capital market, and weakness in the financial intermediation in general. He argues that as a consequence, private businesses find it difficult to contract credit, leading to an apparent lack of competition and hence less efficiency.

Thus, in a total of 133 private firms surveyed by Aryeetey, Steel, et al. (1993) in Ghana, they reported that inadequate financing was the most significant constraint for about $60 \%$ of these companies. Even though it was the most important constraint for the group, it would appear that contracting credit was a serious constraint for the smaller firms (see Adjustment in Africa: Lessons from country case studies; Ghana: Front-runner in adjustment, World Bank, 1994, p178-9, for more on this point).

\footnotetext{
${ }^{7}$ Of course, in practice, different sectors have different risk, uncertainty, and transaction costs and therefore, borrowing cost may not equalise..
}

(C) 2012 The Clute Institute http://www.cluteinstitute.com/ 
An additional contributing factor could be the presence of a moral hazard (where banks prefer to be risk lovers and provide risky loans with high interest rates in expectation that losses would then be covered by the government while gains would accrue to themselves). The cost of borrowing would be likely to expand, leading to increased distress borrowing, increased probability of default, and bank failure (McKinnon, 1989). The above evidence, and other reasons, may suggest that even though the volatility of borrowing cost among different sectors of the economy has increased under the financial liberalisation policy, leading to less efficiency in the allocation of credit, the cause cannot be put on the financial liberalisation policy per se, but rather on some interrelated bottlenecks (both political and economic) that existed and still exist in the financial sector and in the economy as a whole.

\section{Interest Rate Liberalisation and Economic Growth}

According to the McKinnon and Shaw hypothesis, the ultimate goal of financial liberalisation is to generate rapid economic growth. As can be seen in Table 3, annual average GDP growth pre-financial liberalisation was $1.0 \%$, but after the implementation of the policy, the economy was growing at an average rate of $4.8 \%$. One can also notice that the growth rates before financial liberalisation were not steady. There were years when negative rates were recorded - some as low as $-13.4 \%$ in 1975 - while some years recorded positive rates as high as $8.8 \%$ in 1984. However, the post-financial liberalisation period has seen constant positive growth rates from 1991 to 2008 .

Table 3: Selected Macroeconomic Indicators for Ghana between 1975 and 2008

\begin{tabular}{|c|c|c|c|}
\hline Year & GDP Growth Rate (\%) & $\begin{array}{c}\text { Rate of Inflation } \\
\text { (as Measured by CPI), \% }\end{array}$ & Trade Balance (\$m) \\
\hline 1975 & -13.4 & 30.0 & 150.4 \\
\hline 1976 & -3.5 & 56.0 & 88.8 \\
\hline 1977 & 1.8 & 116.0 & 29.4 \\
\hline 1978 & 9.8 & 73.0 & 112.5 \\
\hline 1979 & -1.7 & 54.0 & 262.6 \\
\hline 1980 & 0.6 & 50.0 & 195.3 \\
\hline 1981 & -2.9 & 117.0 & -243.6 \\
\hline 1982 & -6.5 & 22.0 & 18.6 \\
\hline 1983 & -4.4 & 123.0 & -60.6 \\
\hline 1984 & 8.8 & 40.0 & 32.9 \\
\hline 1985 & 5.1 & 10.0 & -36.3 \\
\hline 1986 & 5.1 & 24.8 & 60.9 \\
\hline 1987 & 4.6 & 39.7 & -107.1 \\
\hline 1988 & 5.5 & 31.4 & -112.4 \\
\hline 1989 & 5.0 & 25.3 & -203.4 \\
\hline 1990 & 2.6 & 37.2 & -308.2 \\
\hline Average & 1.0 & 53.1 & -7.5 \\
\hline 1991 & 5.2 & 18.0 & -321.1 \\
\hline 1992 & 3.6 & 10.1 & -470.3 \\
\hline 1993 & 4.8 & 25.0 & -664.3 \\
\hline 1994 & 3.0 & 25.0 & -342.2 \\
\hline 1995 & 4.8 & 59.5 & -256.6 \\
\hline 1996 & 3.0 & 47.0 & -380.7 \\
\hline 1997 & 4.0 & 28.0 & -653.9 \\
\hline 1998 & 5.0 & 15.0 & -900.8 \\
\hline 1999 & 4.0 & 12.0 & -1274.4 \\
\hline 2000 & 4.0 & 25.0 & -803.0 \\
\hline 2001 & 4.0 & 33.0 & -1101.4 \\
\hline 2002 & 5.0 & 15.0 & -691.8 \\
\hline 2003 & 5.0 & 27.0 & -670.4 \\
\hline 2004 & 6.0 & 13.0 & -1592.8 \\
\hline 2005 & 6.0 & 15.0 & -2545.1 \\
\hline 2006 & 6.2 & 11.6 & -3027.0 \\
\hline
\end{tabular}




\begin{tabular}{|c|c|c|c|}
\hline Year & GDP Growth Rate (\%) & $\begin{array}{c}\text { Rate of Inflation } \\
\text { (as Measured by CPI), \% }\end{array}$ & Trade Balance (\$m) \\
\hline 2007 & 6.0 & 12.7 & -3897.2 \\
\hline 2008 & 7.0 & 18.1 & -4192.1 \\
\hline Average & $\mathbf{4 . 8}$ & $\mathbf{2 2 . 8}$ & $\mathbf{- 1 3 2 1 . 4}$ \\
\hline
\end{tabular}

Source: World Bank's African Development Indicators (2009) and IMF International Financial Statistics (2009)

Even though inflation has reduced, on the average, after the financial liberalisation, the level is still high compared to those in other African countries. ${ }^{8}$. The government brought its budget deficit under control just after the financial liberalisation policy was implemented, but the problem appeared again in 1992 and again in 1993. This drastic increase in government spending triggered a rapid increase in the rate of inflation, from a mere $10.1 \%$ in 1992 to about $60 \%$ at the end of 1995 . Inflation has been dropping since then, falling to a low of $11.6 \%$ in 2006 . On the average, post-liberalisation inflation has been about $22.8 \%$, which represents about $57.1 \%$ of the preliberalisation levels.

One negative effect of the financial liberalisation has been the increase in imported consumer goods (IMF, 2009). Even though the deficit is not only in consumer goods, the proportion that constitutes consumer goods has increased significantly. In 1985, the proportion was $47.1 \%$, but as at the end of 1995, it stood at $67.7 \%$, and in 2008, the figure stood at about 70\%. As may be seen in Table 3, Ghana has not recorded any trade surplus since the implementation of the financial liberalisation policy. However, during the pre-liberalisation period, it recorded an average deficit of $\$ 7.5 \mathrm{~m}$ and during the post-liberalisation period, it reflected an average deficit of $\$ 1,321.4 \mathrm{~m}$. The continuation of this trend may not be sustainable in the long run since these (imports) - which are mainly consumer goods - are being financed through the inflow of foreign capital remittances from abroad and external borrowings rather than an increase in domestic productivity and export revenues.

\section{Spreads between Lending and Deposit Rates}

As can be seen in Figure 5, the gap between lending and deposit rates in Ghana has widened significantly since the interest rate liberalisation policy in 1990. Before interest rate liberalisation, the spread between the lending and deposit rates fluctuated between $3.0 \%$ in 1986 and $9.1 \%$ in 1988 and 1989 , with an average of $7.4 \%$ for the period. A 7.5\% spread was maintained between 1978 and 1983. This was reduced to $6.2 \%$ in 1984, then to $5.4 \%$ in 1985, and it was further reduced to its lowest figure of $3.0 \%$ in 1986 before increasing to $7.9 \%$ in 1987. Between 1988 and 1990, the spread was increased and then maintained at $9.1 \%$.

Following the implementation of the full interest rate liberalisation policy in 1991, the spread narrowed significantly - from the previous high of $9.1 \%$ in 1990 to $4.2 \%$ in 1991. Between 1991 and 2008, the interest rate spread varied between a post-liberalisation low of $4.2 \%$ and a historic high $21.4 \%$, with an average spread of $13.5 \%$ for the period to 2008. Between 1997 and 1999, the interest rate spread increased dramatically from $9.8 \%$ in 1997 to $21.4 \%$ in 1999 and to $18.4 \%$ in 2000 before decreasing to $13.1 \%$ in 2001. In 2002, the spread went up again to $19.6 \%$ and then to $21.2 \%$ in 2003.

However, since 2004, the interest rate spread has been stable between $15 \%$ and $16 \%$; thus it was $15.2 \%$ in $2004,15.8 \%$ in $2005,15.4 \%$ in $2006,15.3 \%$ in 2007 , and $16.0 \%$ in 2008.

\footnotetext{
${ }^{8}$ For example, the average inflation of Ivory Coast for the same period has been around $4.5 \%$ per annum, while that of Senegal was 3.3\% (Africa Development Indicators, 2009)
} 


\section{Figure 5: The spread between deposit and lending rates in Ghana from 1978 to 2008}

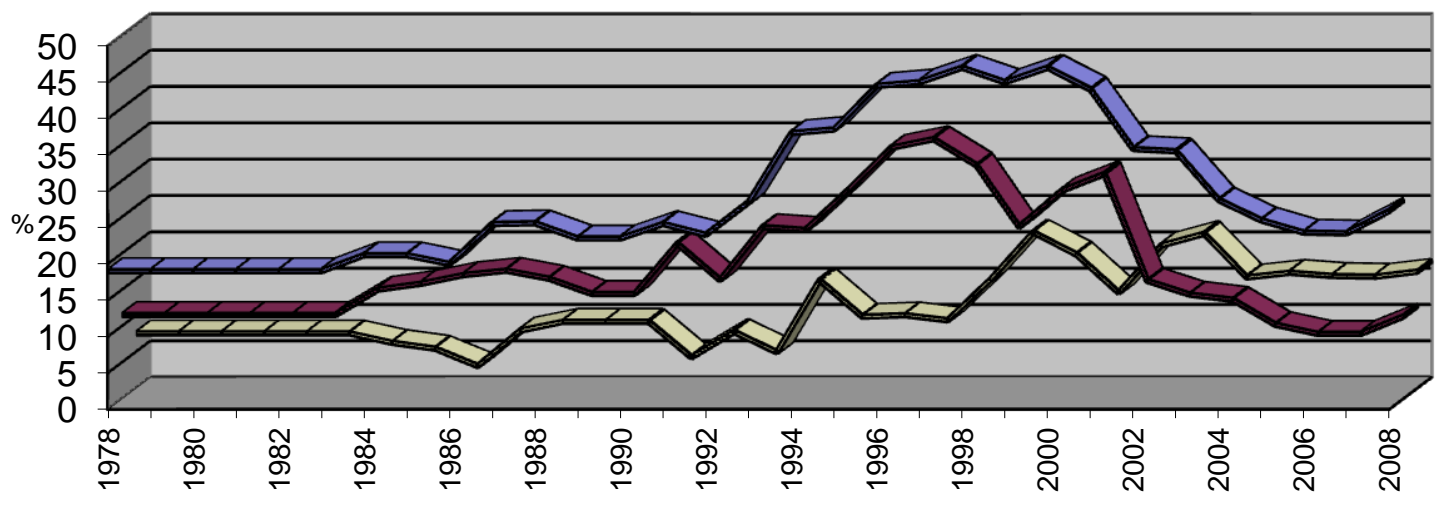

\begin{tabular}{|ll|}
\hline$\square$ Lending rate & adeposit rate \\
\hline
\end{tabular}

Source: Compiled from World Bank’s Africa Development Indicators (2009)

Note: Interest rate spread $=$ Lending rate - Deposit rate

\section{Interest Rate Liberalisation and Foreign Currency Deposits}

Although financial savings have increased since the implementation of the interest rate liberalisation policy (see Table 1), one aspect of this increase is the loss of confidence in the domestic currency, which led to a significant increase in foreign currency deposits in the domestic banks. Based on Table 1, the proportion of total financial savings held in foreign currencies ranged between $0.5 \%$ in 1975 and $18.0 \%$ in 1989, with a yearly average of $5.35 \%$ before the financial liberalisation policy. However, following the liberalisation of the financial sector, these figures increased significantly, from $15.1 \%$ in 1992 to $60.1 \%$ in 1996, with a yearly average of $30.9 \%$. As shown in Table 1, the proportions increased consistently from 1990 to 2008.

The rapid increase in this phenomenon is due to: 1) The rapid depreciation of the domestic currency after the financial liberalisation policy, 2) the relatively high or rampant rates of inflation, 3) the disappearance of the black market dealings in foreign exchange, as a result of the operations of the forex bureaux as well as the acceptance of foreign currencies as deposits by the banks, 4) an inadequate real interest rate, 5) controls on capital markets, and 6) excessive government expenditure.

Furthermore, there is also the granting of credits in foreign currency by the domestic banks to the private sector. Since such loans are repayable in foreign currency, their repayment probability is determined not only by the domestic interest rate, but also by the exchange rate. This has implications for the monetary policies of the Ghanaian financial authorities.

\section{CONCLUSION}

The main aim of this paper is to provide an insight into the role of financial liberalisation in Ghana. Specifically, the study compares the period of pre-liberalisation to that of post-liberalisation in order to evaluate the efficacy of financial liberalisation in Ghana. This paper finds that the evidence so far supports the financial liberalisation hypothesis in Ghana. For example, the study finds that financial savings, which started decreasing 
before financial liberalisation, increased steadily during the third year following liberalisation of the financial sector. Other macroeconomic indicators that improved following the liberalisation of the financial sector include financial deepening, growth, and investment. Although financial liberalisation led to an increase in the quantity of investment, it failed to increase the efficiency of credit allocation in Ghana, even though this decline in the efficiency of credit allocation may not be attributed to the financial liberalisation policy alone. In addition, the study finds that the capital account liberalisation policy led to a relatively large inflow of capital into the country.

\section{AUTHOR INFORMATION}

Erasmus L. Owusu, University of South Africa (UNISA), South Africa. E-mail: erasmus.owusu@talk21.com. Corresponding author.

Nicholas M. Odhiambo, Department of Economics, University of South Africa, P.O Box 392, UNISA, 0003, Pretoria, South Africa. E-mail: odhianm@unisa.ac.za/nmodhiambo@gmail.com

\section{REFERENCES}

1. Aryeetey, E, Steel, W.F. and Baa-Nuakoh, 1993. Background paper on Small and Medium Enterprises demand for finance for the study of meeting the financing needs of Ghana's enterprises, World Bank and National Bureau for Small Scale Industries (NBSSI) in Ghana.

2. Aryeetey, E. 1994. Private investment under uncertainty in Ghana, World Development, Vol. 22: 1211-21

3. Bank of Ghana. 2009. Annual Report (various Issues), Accra, Ghana

4. Cho, YJ. 1988. The effects of Financial liberalisation on the efficiency of credit allocation: Some evidence from Korea, Journal of Development Economics, pp.101-110.

5. Ghana Stock Exchange. 1997, 2009 and 2010. http://www.gse.com.gh/

6. International Monetary Fund (IMF). 2004. The IMF approach to Capital Account Liberalisation, Issues paper/terms of Reference for an evaluation by the Independent Evaluation Office, Washington DC.

7. International Monetary Fund (IMF). 2009. International Financial Statistics Yearbook, various issues to 2009, Washington DC.

8. McKinnon, RI. 1973. Money and capital in Economic development. Washington DC: Brookings Institution.

9. McKinnon, RI. 1989. Financial Liberalization and Economic Development: A Reassessment of Interest Rate Policies in Asia and Latin America. Oxford Review of Economic Policy; Vol.5 (4): 29-54.

10. Owusu, EL. 2011. Financial liberalisation and sustainable economic growth in ECOWAS countries. PhD Thesis, University of South Africa (UNISA), Pretoria, South Africa.

11. Shaw, ES. 1973. Financial deepening in economic development. New York: Oxford University Press.

12. Sowa, NK and Acquaye IK. 1999. Financial and Exchange Rate Market Liberalization in Ghana, Journal of International Development, Vol. 11: 385 - 409

13. World Bank. 1987. World Development Report. New York: Oxford University Press.

14. World Bank. 2009. World Development Report, various issues to 2009, Washington DC.

15. World Bank. 2009. African Development indicators, various issues to 2009, Washington DC 
NOTES 